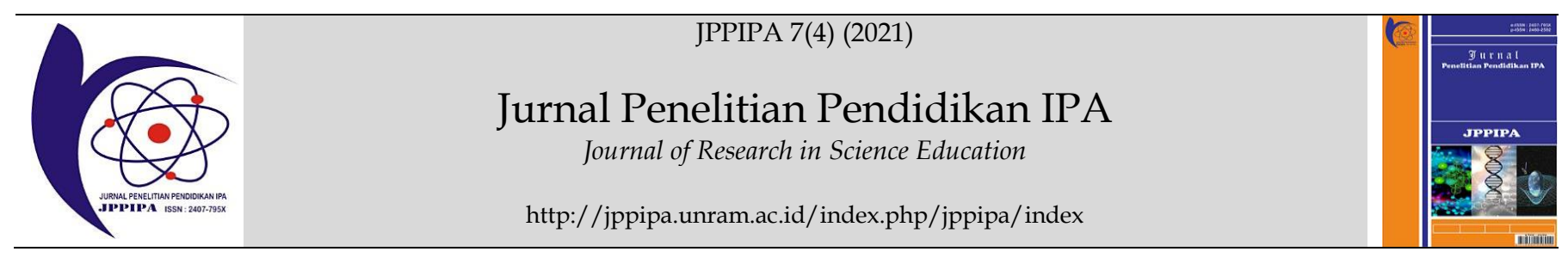

\title{
The Effect of Microhabitat Diversity on the Similarity of Soil Insect Types at Lombok Island, Indonesia
}

\author{
Immy Suci Rohyani $1^{*}$ \\ ${ }^{1}$ Environmental Science Study Program, Faculty of Mathematics and Natural Sciences, University of Mataram, Indonesia.
}

DOI: $10.29303 /$ jppipa.v7i4.807

\section{Article Info}

Received: June $18^{\text {th }}, 2021$

Revised: August 24th 2021

Accepted: October 16th, 2021

\begin{abstract}
Soil insects are a group of organisms whose existence is highly dependent on their microhabitat. Its presence is indispensable because of its ability to reform and decompose organic matter. The presence of soil insects illustrates the functioning of a habitat. This study aims to analyze abiotic and biotic environmental conditions in several types of soil insect habitats on the island of Lombok and securitize the level of similarity of insect species in each of these habitats. The research method used in determining the initial sample point in each habitat is purposive sampling. The parameters observed are those thought to influence the presence of soil insects, including parameters of the abiotic environment and parameters of the biotic environment. The results obtained were that the soil insects found in forest, garden, mangrove, and mining habitats had a high degree of similarity. Forest and garden habitats have a preferred micro-habitat because of the high levels of organic $\mathrm{C}$, moisture, total $\mathrm{N}$, and neural soil $\mathrm{pH}$ as environmental factors that most support the existence of soil insects.
\end{abstract}

Keywords: microhabitat; soil insects; Lombok Island

Citation: Rohyani, I. (2021). The Effect of Microhabitat Diversity on the Similarity of Soil Insect Types at Lombok Island, Indonesia. Jurnal Penelitian Pendidikan IPA, 7(4), 738-745. doi:https://doi.org/10.29303/jppipa.v7i4.807

\section{Introduction}

Soil insects are a group of microarthropods whose existence is highly dependent on their microhabitat. Microhabitat describes habitat conditions suitable for the life of an organism. The response of soil insect groups to environmental conditions determines their ability to use the microhabitat. According to Madej et al. (2011), environmental conditions such as food availability, temperature, humidity, $\mathrm{pH}$, and light intensity vary from one microhabitat to another. Soil insect microhabitats can be found in soil, litter, moss, underwood, leaves, and water (Gergocs et al., 2011).

Soil insects are one of the dominant communities in soil habitat. Its presence is indispensable because of its ability to remodel and decompose organic matter. According to Rohyani (2020), soil insects play a role in overhauling organic material, parasites, and predators in the soil ecosystem. Soil insects have the ability to convert organic matter in the soil and then return it back to the soil as organic matter that is ready to be used by plants (Basna et al., 2017). Soil insects also have a large number of individuals. According to Samways (2018), Insects are one of the groups of animals that have a high level of diversity and a high number of individuals covering $70 \%$ of all species on earth. High diversity causes food web processes to run normally and are able to maintain stability in nature (Basna et al., 2017). Soil insects have strong ecological interactions with their environment, so they have the potential to be used as bioindicators in an ecosystem (Yuniar \& Haneda, 2015). According to Doles et al. (2001), the biological index of soil quality can be determined based on the types of microarthropods found in the soil. Cerambycidae (Coleoptera), Trichogrammatidae (Hymenoptera), Cicindelidae (Coleoptera), Tenebrionidae (Coleoptera), and Acroceridae (Diptera)

\footnotetext{
*Email: immysuci@yahoo.co.id
} 
are types of soil insects that have potential as bioindicators in natural forests, mangroves, rice fields, and mines (Rohyani, 2020). Collembola is used as a bioindicator to monitor the success of revegetation in the mine (Rohyani et al., 2013).

The existence of soil insects' populations, types, and activities depends on environmental factors (abiotic and biotic). Abiotic environmental factors affect such as temperature, water content, $\mathrm{pH}$, and organic content. While the biotic factors such as plants, microflora, and other animal groups. The existence of these abiotic and biotic factors greatly affects the presence of soil surface insects (Suin, 2012). According to Suhardjono et al. (2012), soil insects have a tolerance to microhabitat conditions. The availability of ideal microhabitat conditions is the cause of the diversity of microarthropods that differ from one microhabitat to another.

This study aims to analyze the abiotic and biotic environmental conditions in several types of soil insect habitats on the island of Lombok and see the level of similarity of insect species in each of these habitats. This research is expected to provide an overview of the most suitable microhabitat conditions for soil insects in order to increase their role in the sustainable management of soil ecosystems.

\section{Method}

This research was conducted in several types of habitats on the island of Lombok. The research location chosen was a habitat known to be the most commonplace for soil insects to be found. The locations of this research are Forest habitat (East Lombok), Mangrove habitat (West Lombok), Garden habitat (West Lombok) and rice field habitat (West Lombok), mine habitat (West Lombok).

Determination of initial sample points in each habitat was carried out by the purposive sampling method. The parameters observed were parameters that were thought to affect the presence of soil insects, including abiotic environmental parameters and biotic environmental parameters.

Some abiotic environmental parameters are measured directly in the field, and some are analyzed in the laboratory. Parameters measured directly in the field were soil temperature, soil moisture, field $\mathrm{pH}$, and soil salinity. The abiotic environmental parameters analyzed in the laboratory include moisture content, $\mathrm{pH}\left(\mathrm{H}_{2} \mathrm{O}\right)$, organic $\mathrm{C}$, available $\mathrm{K}$, total $\mathrm{K}$, total $\mathrm{N}, \mathrm{C} / \mathrm{N}$ ratio, available $\mathrm{P}$, total $\mathrm{P}$. Sample analysis was carried out on litter and soil. Soil and litter sampling in the field was carried out using the composite method, namely taking soil and litter samples at sample plot points at each research location, then the soil samples were combined and mixed until evenly distributed, then analyzed based on their habitat.

The biotic environmental parameter observed was the number of vegetation types found inside plots in each habitat. The litter thickness in each sample plot was measured using a ruler to determine the thickness of the litter at each observation location.

Soil insect sampling was carried out by making a $100 \mathrm{~m}$ mainline transect at each study site. Every 10 meters distance, an additional transect line perpendicular (horizontal) 5 meters to the right and left is made on the main transect line. At each point that has been made on the main transect and additional transects, five soil insect trapping methods were randomly installed, namely 1) pitfall trap, 2) bait pitfall trap, 3) yellow pan trap, 4) soil sampling, and 5) litter collection. The collected soil and litter were then stored using calico sacks for further extraction in a modified barley funnel for seven days. The number of traps installed was 10 for each collection method at each research location, with a duration of installation for each trap for three days. Furthermore, the soil insects obtained were counted in number and separated by type.

Data analysis to see the level of similarity of insect families in each habitat type used the Jaccard Index (Similarity Index). The Jaccard species similarity index (CJ) value is close to 1 , indicating a high level of similarity between habitats. If the Jaccard species similarity index (CJ) value is close to 0 , it indicates a low level of similarity between habitats.

$$
\mathrm{CJ}=\mathrm{J} /(\mathrm{a}+\mathrm{b}-\mathrm{J})
$$

Description:

$\mathrm{CJ}=$ Jaccard similarity index

$\mathrm{J}=$ number of species found in habitats $\mathrm{a} \& \mathrm{~b}$

$a=$ number of species found in habitat a

$b=$ number of species found in habitat $b$

\section{Result and Discussion}

\section{Characteristics of abiotic and biotic environments in various types of habitats on the island of Lombok}

The existence of soil insects is strongly influenced by environmental factors, both the abiotic and biotic environments of the soil. Abiotic environmental factors can be in the form of physical properties and chemical properties of the soil. Biotic environmental factors include the abundance of soil insects, species richness, vegetation composition, and litter thickness. Based on the results of measurements of environmental factors and analysis of soil and litter, it can be seen that forest habitats have the highest soil water content with the highest soil organic C content 
and the highest percentage of total $\mathrm{N}$ and $\mathrm{K}$ soil exchanged. The measurement of the lowest air temperature in forest habitats is in line with the highest level of air humidity. Mangrove habitat has the highest $\mathrm{C} / \mathrm{N}$ ratio in a litter, with low soil $\mathrm{pH}$ levels or tends to be acidic.

Table 1. Results of measurement and analysis of abiotic factors in several habitat types

\begin{tabular}{|c|c|c|c|c|c|c|}
\hline \multirow{2}{*}{ No } & \multirow{2}{*}{ Parameters Measured } & \multicolumn{5}{|c|}{ Habitat Types } \\
\hline & & Forest & Mangrove & Garden & Rice Field & Mine \\
\hline 1 & Moisture Content (\%) Soil & 5.10 & 1.00 & 4.60 & 2.70 & 1.20 \\
\hline 2 & Water Content (\%) Litter & 0.60 & 0.50 & 0.50 & 1.10 & 1.00 \\
\hline 3 & C-Organic (\%) Soil & 5.88 & 0.32 & 4.53 & 0.14 & 0.77 \\
\hline 4 & C-Organic (\%) Litter & 34.35 & 34.57 & 33.57 & 28.49 & 35.74 \\
\hline 5 & N Total (\%) Land & 0.47 & 0.02 & 0.46 & 0.04 & 0.08 \\
\hline 6 & N Total (\%) Litter & 0.97 & 0.42 & 0.96 & 1.06 & 0.72 \\
\hline 7 & C/N Litter Ratio & 35.35 & 81.90 & 35.09 & 26.86 & 50.56 \\
\hline 8 & P Available (Ppm) Soil & 21.38 & 14.76 & 35.40 & 53.31 & 61.49 \\
\hline 9 & P Total (\%) Litter & 0.09 & 0.01 & 0.08 & 0.12 & 0.13 \\
\hline 10 & K-Switched (Meq) Land & 2.19 & 1.90 & 1.45 & 0.87 & 0.51 \\
\hline 11 & K Total (\%) Litter & 0.99 & 0.67 & 0.58 & 1.12 & 2.44 \\
\hline 12 & $\mathrm{pH} \mathrm{H}{ }_{2} \mathrm{O}$ & 7.00 & 8.00 & 7.00 & 5.00 & 8.00 \\
\hline 13 & Field $\mathrm{pH}$ & 5.00 & 4.00 & 5.00 & 6.00 & 4.00 \\
\hline 14 & Soil Temperature & 22.00 & 28.00 & 24.00 & 27.00 & 28.00 \\
\hline 15 & Humidity & 101.00 & 72.00 & 83.00 & 59.00 & 73.00 \\
\hline 16 & Salinity & 0.00 & 24.00 & 0.00 & 0.00 & 0.00 \\
\hline
\end{tabular}

The composition of vegetation and the distribution of litter is one of the factors that affect the presence of soil insects. According to Rahmadi et al. (2004), the diversity of vegetation will indirectly affect the diversity of soil insects. Diversity of vegetation will provide a wide variety of feed. The higher the variety of feeding, the more diverse organisms that can consume it. The increasing number of vegetation types causes higher litterfall and thickness so that the availability of food sources for soil insects will be better and more diverse and can increase soil organic matter content (Sebayang et al. 2000). Thick litter can create a suitable microclimate for soil fauna habitat. Litter that is on the ground surface is a source of food for various organisms, especially organisms that play a role in degrading litter (Rohyani et al., 2013). According to Materna (2004), the diversity and density of high ground cover vegetation affect the increasing number of soil macropores that soil insect groups can utilize as a shelter from predators.

Table 2. Characteristics of the biotic environment in several habitat types on the island of Lombok

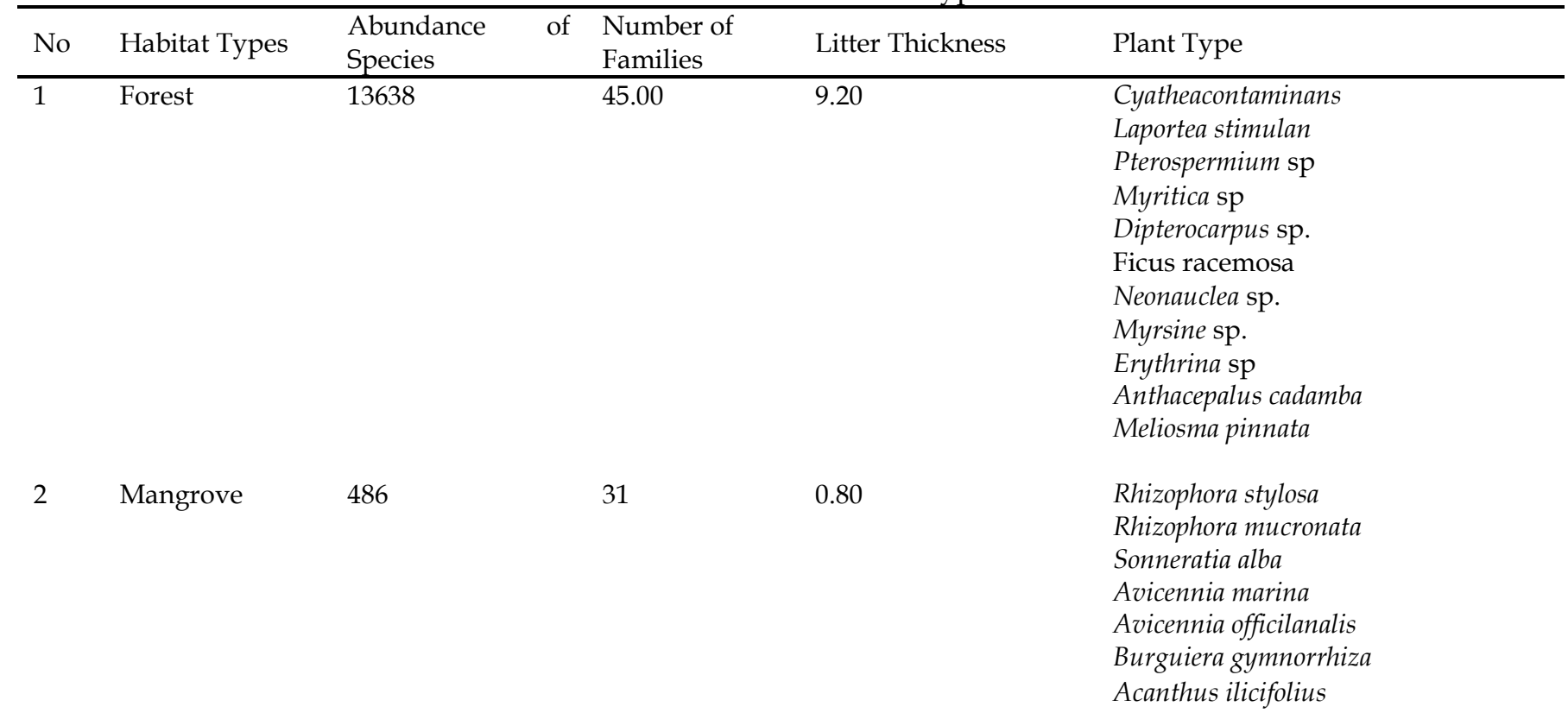




\begin{tabular}{|c|c|c|c|c|c|c|}
\hline No & Habitat Types & $\begin{array}{l}\text { Abundance } \\
\text { Species }\end{array}$ & of & $\begin{array}{l}\text { Number of } \\
\text { Families }\end{array}$ & Litter Thickness & Plant Type \\
\hline 3 & Mixed Garden & 39441 & & 46.00 & 7.50 & $\begin{array}{l}\text { Nephelium lappaceum } \\
\text { Musa acuminata } \\
\text { Durio zibethinus. } \\
\text { Chrysophyllum cainito } \\
\text { Ceiba pentandra }\end{array}$ \\
\hline
\end{tabular}

Environmental factors such as temperature and soil moisture in several habitat types observed on the island of Lombok are not much different (Table 1). In forest habitats, the air temperature is lower with relatively high humidity compared to other habitat types. This is due to a large number of trees with high crowns in this habitat, causing the intensity of sunlight that enters the forest floor to decrease because tree crowns block it. This condition affects the surrounding temperature. According to \& Zaidatun (2007), Plants can increase soil moisture and produce a litter that is favored by soil fauna. According to Sulandjari et al. (2005), the humidity is higher if the light intensity is lower. Changes in temperature and humidity also affect the abundance of soil insects which are also high in forest habitats. Each temperature increases of more than $4 \mathrm{oC}$ in the pine forests of Northern Latvia causes the species richness of the soil Collembola insect to decrease (Jucevica and Meleis, 2005).

The results of the analysis of soil water content in forest and garden habitats showed the highest percentage compared to other habitats. This condition affects the abundance of soil insects which are also high in both habitats. The results of this study are in line with Husamah et al. (2015) that soil water content has a significant effect on the number of individuals and the number of insect species, especially Collembola in agricultural habitats. According to Nurhadi \& Widiana (2009), soil moisture or water content determines the presence of ground surface animals. Soil moisture is generally defined as water held in the spaces between soil particles. Soil moisture is an important parameter for many hydrological, biological, and chemical processes. Related to soil moisture, soil insect groups also have the potential to be used as bioindicators of soil conditions.

Forest habitats and garden habitats had the highest soil organic C content with the highest percentages of total $\mathrm{N}$ and soil exchanged $\mathrm{K}$ (Table 1). The large value of C-organic in forest habitat and garden habitat indicates that both habitats have high organic matter content. The high organic matter affects the soil's physical, chemical, and biological properties, one of which is total $\mathrm{N}$ and soil exchanged $\mathrm{K}$. According to Hardjowigeno \& Rayes (2010), the value of Cation Exchange Capacity is closely related to soil fertility. Soils with high cation exchange capacity are able to absorb and provide nutrients better than soils with low cation exchange capacity. Soil with a high Cation Exchange Capacity, when dominated by alkaline cations, can increase soil fertility. High soil moisture affects the accumulation of organic matter and nitrogen in the soil (Yulipriyanto, 2010). Soil that contains high organic $\mathrm{C}$ is also a habitat for groups of fungi and microbes.

Mangrove habitat has the highest $\mathrm{C} / \mathrm{N}$ ratio in a litter. This condition illustrates that the nitrogen content in the observed mangrove habitat is still low. The relatively low $\mathrm{N}$ content will cause the degradation process to take place more slowly because nitrogen will be a growth-rate limiting factor (Wulan et al., 2011). Furthermore, according to Aprianis (2011), that C/N is one indicator to see the rate of decomposition of organic matter because the overhaul of organic matter will reduce the $\mathrm{C} / \mathrm{N}$ of the litter.

In the mangrove habitat, the $\mathrm{pH}$ level of $\mathrm{H}_{2} \mathrm{O}$ tends to be high. This condition is inversely proportional to the results of field soil $\mathrm{pH}$ 
measurements which tend to be low or acidic. The range of soil $\mathrm{pH}$, both $\mathrm{pH}$ in the field and $\mathrm{pH} \mathrm{H}_{2} \mathrm{O}$, varies from $\mathrm{pH} 4$ to 8 . This means that the soil has a high acidity to neutral. The presence of soil fauna depends on the $\mathrm{pH}$ of the soil. Soil fauna tends to live in neutral pH soils (Suin, 2012). Soil acidity determines the solubility of soil minerals and affects the activities of soil microorganisms, such as the decomposition of organic matter and nitrogen fixation. This condition is thought to be the cause of the high $\mathrm{C} / \mathrm{N}$ ratio in the mangrove habitat.

According to Hardjowigeno \& Rayes (2010), soil $\mathrm{pH}$ can also affect the development of soil organisms, and acidic $\mathrm{pH}$ will affect the slow destruction of organic matter. The $\mathrm{pH}$ of the soil is slightly acidic due to the overhaul of mangrove vegetation litter by soil microorganisms that produce organic acids, thereby lowering soil pH (Setiawan 2013). Organic matter can affect the size of the soil's absorption of water. The more water in the soil, the more the reaction to release $\mathrm{H}^{+}$ions makes the soil acidic. Fluctuations in soil $\mathrm{pH}$ values can be caused by variations in the composition of stand vegetation and soil organic matter content. The decomposition of soil organic matter is carried out by microorganisms, root secretions, or oxidation of inorganic materials (Fao, 2009).

The water content and $\mathrm{N}$ total litter had the highest percentage in the rice field habitat among other habitats. The results of measurements of $\mathrm{pH} \mathrm{H}_{2} \mathrm{O}$ in rice fields tend to be low or acidic. The percentage of organic $\mathrm{C}$ content in the litter, total $\mathrm{K}$, available $\mathrm{P}$ in the litter and total $\mathrm{P}$ in the soil, and the highest total $\mathrm{K}$ in the litter in mining habitats with the results of field $\mathrm{pH}$ measurements that tend to be low or close to acid (Table 1). High organic C content indicates a high amount of organic matter in the soil. According to Fitriana (2006), sources of organic matter are in the form of litter and plant remains that enter the substrate. In general, organic matter can maintain soil aggregation and moisture, provide energy for soil organisms and provide nutrients for plants. Organic matter has a productive function that supports plant biomass production and a protective function to maintain soil fertility and soil biotic stability (Setiawan, 2013). These results are in line with the studies of Eaton et al. (2004) that there is a positive correlation between the number of individual soil insects and the C-organic content of the soil. This is possible because most soil insects live in a litter that contains high soil organic matter.

The high total $\mathrm{K}$ and $\mathrm{P}$ elements in the soil in mining habitats can come from organic matter, fertilization, or minerals in the soil. The high value of $\mathrm{K}$ is also influenced by soil temperature, which is also the highest in the habitat. The increase in $\mathrm{K}$ value was due to the faster decomposition of organic matter. Factors that affect the availability of $\mathrm{P}$ in the soil include $\mathrm{pH}$, soil organic matter, and soil texture so that in each type of soil, the availability of phosphorus is different according to the characteristics of the soil (Ariawan \& Prahastuti, 2016).

Habitat Forests and gardens have a high level of litter thickness and a high number of vegetation types, while mangrove habitats have very low litter thickness (Table 2). The thickness of the litter is influenced by the high and low humidity and soil temperature. Humidity and soil temperature can accelerate the process of decomposition of organic matter. Generally, the composition of organic matter occurs more quickly in hot climates. In the dry season, litter production is relatively higher than in the rainy season. Another factor that affects litter thickness is the high number of vegetation types. This statement is reinforced by Zamroni \& Rohyani (2007); Soeroyo (2003) that the thickness of the litter layer is influenced by the density of vegetation, the types of plants that make up the vegetation, the age of the vegetation, and the local climatic conditions. According to Zayadi et al. (2013), differences in the abundance of soil insect species are influenced by the diversity of vegetation, environmental conditions, and the thickness of litter in the habitat.

Litter thickness is one of the important factors affecting the presence of soil insects in a habitat. The composition and type of leaf litter determine the density of soil insects that can live there. According to Suhardjono et al. (2012), litter quality and thickness of the litter layer and soil organic matter content will affect the soil microhabitat and affect the life and abundance of soil insects. Litter is the most preferred shelter and food source for soil insects. Thick and moist litter also provides the most preferred microbite by soil insects (Rahmadi et al., 2004). According to Rohyani (2012), the pattern of the relationship between the abundance of soil insects and the thickness of the litter shows a positive relationship between the increasing number of individual soil insects and the thickness of the litter. The decomposition of litter produces a number of organic materials that can support the life of living things (soil biota). The more litter, the more material for decomposition, so the number of decomposers is also greater (Buliyansih, 2005).

\section{The effect of microhabitat diversity on the level of similarity of soil insects}

The results of the calculation of the Jaccard similarity value show similarities in the family of soil insects in garden and mangrove habitats (0.51) and garden and mining habitats (0.50). The low Jaccard 
value in the rice field and mangrove habitat (0.29) indicates that the level of similarity between the soil insect families in the two habitats is low (Table 3). The high similarity value of soil insects in garden habitats with mangrove habitats and garden habitats with mining habitats is thought to be related to the similarity of physical and chemical environmental conditions between these habitats, namely litter water content, litter organic $\mathrm{C}$ content, and total litter $\mathrm{P}$, soil $\mathrm{pH}$, soil temperature, soil moisture and several types of constituent vegetation, especially for garden habitats and mining habitats.

Physical and chemical factors of soil and litter are limiting factors for soil insect life so that it will indirectly affect the diversity of soil insects (Mas'ud \& Sudandari, 2011). According to Suin (2012), the content of organic matter, water content, and temperature is directly proportional to the presence of soil insects. If soil insects are in suitable abiotic environmental conditions, the presence of soil insects will increase.

Table 3. Matrix of Jaccard similarity index (CJ) values in various habitat types

\begin{tabular}{llcccc}
\hline Location & Forest & Mangrove & $\begin{array}{c}\text { Garden Rice } \\
\text { Field }\end{array}$ & Mine \\
\hline Forest & 1.00 & & & & \\
Mangrove & 0.31 & 1.00 & & \\
Garden & 0.40 & 0.51 & 1.00 & & \\
Rice Field & 0.38 & 0.29 & 0.35 & 1.00 & \\
Mine & 0.46 & 0.30 & 0.50 & 0.46 & 1.00 \\
\hline
\end{tabular}

In garden habitats and mining habitats, there are similarities in the types of vegetation that dominate them. This condition is thought to have influenced the level of similarity of soil insect families in these habitats. Vegetation is the main source of organic matter in the soil, a source of food and shelter for soil insects. Vegetation can also affect physical and chemical environmental conditions. According to Suahardjono et al. (2012), vegetation is one of the ecological system components that contributes to the formation of the soil insect community, namely Collembola. The low level of similarity in the rice field habitat and mangrove habitat due to environmental factors and vegetation types are very different in the two habitats. Rice field habitats have a $\mathrm{pH}$ of $\mathrm{H}_{2} \mathrm{O}$ which tends to be low or acidic, while mangrove habitats have a $\mathrm{pH}$ of $\mathrm{H}_{2} \mathrm{O}$ which tends to be alkaline. This condition is closely related to the high water content of rice fields. The more water in the soil, the more the reaction to release $\mathrm{H}+$ ions so that the soil becomes acidic and vice versa. Soil $\mathrm{pH}$ is a limiting factor for the life of soil organisms (soil insects) either directly or indirectly (Suahardjono et al., 2012).

\section{Conclusion}

Based on the research results, it can be concluded that the forest and garden floors have the preferred microhabitat due to the high levels of organic $\mathrm{C}$, moisture, total $\mathrm{N}$, and neutral soil $\mathrm{pH}$ as environmental factors that most support the existence of soil insects. Soil insect families found in forest, garden, mangrove, and mining habitats have a high degree of similarity. In the rice field and mangrove habitats, the family similarity level is relatively low, presumably due to differences in microhabitats such as $\mathrm{C} / \mathrm{N}$ ratio, available $\mathrm{P}$ and $\mathrm{pH}$, and very different vegetation types in the two habitats.

\section{Acknowledgments}

The authors would like to thank various parties who have contributed to this research regarding the permit for the sampling location and the use of the laboratory for analysis and identification.

\section{References}

Aprianis, Y. (2011). Produksi dan Laju Dekomposisi Serasah Acacia Crassicarpa A.Cunn. Di PT. Arara Abadi. Jurnal Tekno Hutan Tanaman. 4(1):41-47p. [Indonesian]

Ariawan I.M.R., Thaha A.R., \& Prahastuti, S.W. (2016). Pemetaan Status Hara Kalium Pada Tanah Sawah Di Kecamatan Balinggi, Kabupaten Parigi Moutong, Provinsi Sulawesi Tengah. E-J. Agrotekbis 4 (1): 43- 49. [Indonesian]

Basna, M., Koneri, R., \& Papu, A. (2017). Distribusi Dan Diversitas Serangga Tanah Di Taman Hutan Raya Gunung Tumpa Sulawesi Utara. Jurnal Mipa Unsrat Online, 6(1), 36-42. doi: https://doi.org/10.35799/jm.6.1.2017.16082 [Indonesian]

Buliyansih, A. (2005). Penilaian Dampak Kebakaran Terhadap Makrofauna Tanah Dengan Metode Forest Health Monitoring (FHM). Repository IPB. Retrieved from: Http://Repository.Ipb.Ac.Id/Bitstream/Handle $\angle 123456789 / 11367 /$ E05abu.Pdf?Sequence=2.121 P [Indonesian]

Doles, J., Zimmerman, R., \& Moore, J. (2001). Soil microarthropod community structure and dynamics in organic and conventionally managed apple orchards in Western Colorado, USA. Applied Soil Ecology, 18, 83-96. https://doi.org/10.1016/S0929-1393(01)00143-3. 
Eaton, Andrew, Et.Al. (2005). Standard Methods For Examination Of Water And Wastewater.21 ${ }^{\text {st }}$ Edition. Marryland -Usa : American Public Health Association

Fao. (2009). The Importance of Soil Organic Matter. Article. Retrieved from: http://www.fao.org/docrep/009/a0100e/a0100 e0d.htm.

Fitriana, Y. R. (1970). Diversity and abundance of macrozoobenthos in mangrove rehabilitation forest in Great Garden Forest Ngurah Rai Bali. Biodiversitas Journal of Biological Diversity, 7(1), 67-72.

https://doi.org/10.13057/biodiv/d070117.

Gergocs, V., Ágnes, G., Homorodi, R., \& Hufnagel, L. (2009). Seasonal change of oribatid mite communities (Acari, Oribatida) in three different types of microhabitats in an oak forest. Applied Ecology and Environmental Research, 9, 181-195.

Hardjowigeno, S., \& Rayes, M. L,. (2010).Tanah Sawah. Bayumedia, Malang. [Indonesian]

Husamah, H., Rohman, F., \& Sutomo, H. (2015, April 4). Pengaruh C-Organik dan Kadar Air Tanah terhadap Jumlah Jenis dan Jumlah Individu Collembola Sepanjang Daerah Aliran Sungai Brantas Kota Batu. Conference: Symposium on Biology Education. Retrieved from: http://research-report.umm.ac.id/i...view/539 [Indonesian]

Jucevica, E., \& Melecis, V. (2005). Long-Term Effects of Climate Warming on Forest Soil Collembola. Acta Zoologica Lituanica, 15(2), 124-126. https://doi.org/10.1080/13921657.2005.1051238 7.

Madej, G., Barczyck G., \& Gawena, I. (2011). Importance of Microhabitats for Preservation of Spesies Diversity, On the Basis Mesostigmatid Mites (Mesostigmata, Arachnida, Acari). Polish J. Of Environ. Stud., 20(4): 961-968. Retrieved from: http://www.pjoes.com/Issue-1-2011,3836

Mas'ud A, \& Sundari. (2011). Kajian Struktur Komunitas Epifauna Tanah di Kawasan Hutan Konservasi Gunung Sibela Halmahera Selatan Maluku Utara. Bioedukasi. 2(1): 7-15, doi: http://dx.doi.org/10.24127/bioedukasi.v2i1.196 [Indonesian]

Materna, J. (2004). Does forest type and vegetation patchiness influence horizontal distribution of soil Collembola in two neighbouring forest sites? Pedobiologia - Journal of Soil Ecology, 48(4), 339347.

https://doi.org/10.1016/j.pedobi.2004.04.003.

Nurhadi, \& Widiana, R. (2009). Komposisi Arthropoda Permukaan Tanah Di Kawasan Penambangan Batubara Di Kecamatan Talawi Sawahlunto.
Jurnal Sains Dan Teknologi. 1(2). doi: http://dx.doi.org/10.31958/js.v2i1.7 [Indonesian]

Nusroh \& Zaidatun. (2007). Studi Diversitas Makrofauna Tanah Di Bawah Beberapa Tanaman Palawija Yang Berbeda Di Lahan Kering Pada Saat Musim Penghujan. Jurnal Penelitian UNS: Surakarta. Retrieved from: https://digilib.uns.ac.id/... -musim-penghujan [Indonesian]

Rahmadi, C., Suhardjono, Y.R., \& Andayani, I. (2004). Collembola Lantai Hutan Kawasansungai Tabalong Kalimantan Selatan. Biota: Jurnal Ilmiah Ilmu Hayat. 9(3), 179-185. doi: https://doi.org/10.24002/biota.v9i3.2915 [Indonesian]

Rohyani, I.S. (2020). Community structure analysis of soil insects and their potential role as bioindicators in various ecosystem types in Lombok, West Nusa Tenggara, Indonesia. Biodiversitas. 21(9), 4221-4227. doi https://doi.org/10.13057/biodiv/d210937

Rohyani, I.S., Jaya, INS, Haneda, N.F, \& Kusumah, Y.M. (2013). Kelimpahan Collembola Tanah Untuk Pendugaan Waktu Pencapaian Keberhasilan Revegetasi Dari Aspek Kesuburan Tanah Di Area Tambang PT. Newmont Nusa Tenggara. Forum Pascasarjana. 36(2) :69-78 [Indonesian]

Rohyani, I.S. (2012). Permodelan Spasial Kelimpahan Collembola Tanah Pada Area Revegetasi Tambang PT Newmont Nusa Tenggara. Disertasi Program Pascasarjana IPB. Bogor. [Indonesian]

Samways, M. J. (2018). Insect Conservation for The Twenty-First Century. In: Shah, M.M. \& Syarif, U. (Eds.). Insect Science-Diversity, Conservation and Nutrition. London: Intechopen. Pp. 19-40. doi: http://dx.doi.org/10.5772/intechopen. $\underline{71639}$.

Sebayang D, Suryati T., \& Adianto. (2000). Keanekaragaman Dan Kelimpahan Artropoda Tanah Di Hutan Alami, Hutan Pinus, Kebun Sayur Dan Lahan Terbuka Di Gunung Tangku banparahu. Prosiding Simposium Keanekaragaman Hayari Artropoda Pada Sistem Produksi Pertanian. Cipayung, 16-18. [Indonesian]

Setiawan, H. (2013). Status Ekologi Hutan Mangrove Pada Berbagai Tingkat Ketebalan. Jurnal Penelitian Kehutanan Wallacea, 2(2), 104. https://doi.org/10.18330/jwallacea.2013.vol2iss 2pp104-120 [Indonesian]

Soeroyo. (2003). Pengamatan Gugur Serasah Di Hutan Mangrove Sembilang Sumatra Selatan. P3o-Lipi: 38-44 [Indonesian]

Suhardjono, Y.R., Louis D.M., \& Anne D. (2012). 
Collembola (Ekor Pegas). Vegamedia, Bogor. P. 19282.

Suin, N. M. (2012). Ekologi Hewan Tanah. Jakarta. Bumi Aksara. [Indonesian]

Sulandjari, S. Pramono, S. Wisnubroto, \& D. Indradewa. (2005). Hubungan mikroklimat dengan pertumbuhan dan hasil pule pandak (Rauvolfia serpentina Benth.). Agrosains. 7(2): 71-76. [Indonesian]

Wulan, P.P.D.K. (2011). Penentuan Rasio Optimum C:N:P Sebagai Nutrisi Padaproses Biodegradasi BenzenaToluena Dan Scale Up Kolom Bioregenerator. Fakultas Teknik. Universitas Indonesia. Depok. [Indonesian]

Yulipriyanto, H. (2010). Biologi Tanah Dan Strategi Pengolahannya. Yogyakarta: Graha Ilmu. [Indonesian]

Yuniar, N., \& Haneda, N. F. (2015). Keanekaragaman Semut (Hymenoptera: Formicidae) Pada Empat Tipe Ekosistem Yang Berbeda Di Jambi. Prossiding Seminar Nasional Masyarakat Biodiversitas Indonesia, 1(7), 1582-1585. https://doi.org/10.13057/psnmbi/m0107 [Indonesian]

Zamroni, Y., \& Rohyani, I. (2008). Produksi Serasah Hutan Mangrove di Perairan Pantai Teluk Sepi, Lombok Barat (Litterfal Production at Mangrove Forest in the Beach Water of Sepi Bay, West Lombok). Biodiversitas, 9, 284-287. [Indonesian]

Zayadi, H., Hakim, L., \& Leksono, A. (2013). Composition and Diversity of Soil Arthropods of Rajegwesi Meru Betiri National Park. Journal of Tropical Life Science, 3(3), 166-171. Retrieved from https://jtrolis.ub.ac.id/index.php/jtrolis/article $\angle$ view/94. 